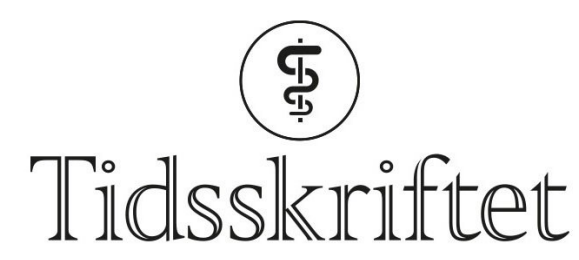

DEN NORSKE LEGEFORENING

\title{
Kvetiapin brukes for mye
}

DEBATT

\section{PÅL GJERDEN}

E-post: pal.gjerden@sthf.no

Pål Gjerden er dr.philos., spesialist i psykiatri og overlege ved Sykehuset Telemark, Skien

Forfatter har fylt ut ICMJE-skjemaet og oppgir ingen interessekonflikter.

\section{J RGEN G. BRAMNESS}

Jørgen G. Bramness er dr.med., spesialist i psykiatri og seniorforsker ved Nasjonal kompetansetjeneste for samtidig rusmisbruk og psykisk lidelse (N-ROP), Sykehuset Innlandet, Hamar og professor II, Institutt for klinisk medisin, Det helsevitenskapelige fakultet, Universitetet i Troms $\emptyset$ - Norges arktiske universitet.

Forfatter har fylt ut ICMJE-skjemaet og oppgir ingen interessekonflikter.

\section{LARS SLØRDAL}

Lars Slørdal er spesialist i klinisk farmakologi, professor ved Institutt for klinisk og molekylær medisin, Norges teknisk-naturvitenskapelige universitet og overlege ved Avdeling for klinisk farmakologi, St. Olavs Hospital.

Forfatter har fylt ut ICMJE-skjemaet og oppgir ingen interessekonflikter.

Antall brukere av det antipsykotiske medikamentet kvetiapin $\emptyset$ ker dramatisk. Det brukes nærmest utelukkende på andre indikasjoner enn behandling av psykoser.

Kvetiapin ble lansert i Norge med salgsnavnet Seroquel i 2003. Mens salget av alle andre antipsykotiske medikamenter har vært stabilt, øker salget av kvetiapin, og midlet kan bli markedsledende i antipsykotikagruppen allerede inneværende år. Økningen skyldes at stadig flere pasienter får forskrevet stadig lavere doser, mest sannsynlig på andre indikasjoner enn psykose (1). Siden disse funnene ble publisert, har antall brukere av kvetiapin $ø$ kt ytterligere ( fig $_{1}$ ). 


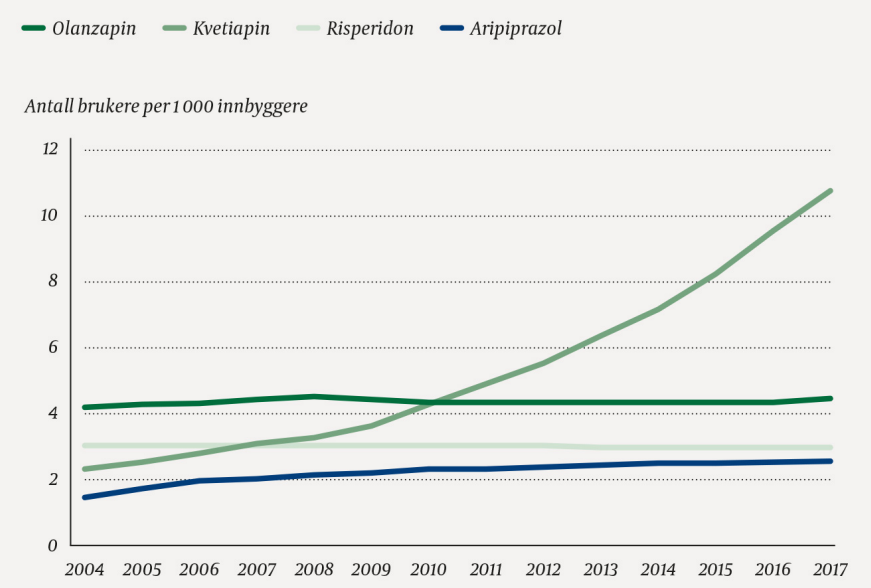

Figur 1 Antall brukere per 1 ooo innbyggere for de fire mest solgte antipsykotika i Norge 2004-17. Data fra Reseptregisteret

\section{Hvem kan bruke kvetiapin?}

Kvetiapin har markedsføringstillatelse for schizofreni, mani og bipolar depresjon. Refusjon er forhåndsgodkjent for schizofreni og mani, men ikke for depresjon. I Helsedirektoratets retningslinje fra 2012 er kvetiapin anbefalt som et førstevalg ved bipolar depresjon (2). I praksis blir medikamentet sannsynligvis refundert både for mani og depresjon under punkt F3. Det anbefales ikke til barn og ungdom under 18 år.

Reseptregisterets database inneholder poliklinisk utleverte resepter fra apotek, men ikke presise diagnoser eller indikasjon. Refusjon etter punkt $\mathrm{F}_{2}$ indikerer bruk hos pasient med psykose, men ikke nødvendigvis som behandling for psykosen. Hvis pasienten har fătt forskrevet døgndoser store nok til å kunne ha en antipsykotisk effekt, kan dette brukes som indikator på at medikamentet brukes som indisert. Kvetiapin har en definert døgndose på $400 \mathrm{mg}$. Vanlige doser i psykoseterapi er 400-80o mg, mens anbefalt dosering ved depresjon er 300-800 mg.

\section{Hvem bruker kvetiapin?}

Median estimert døgndose for pasienter som fikk to eller flere resepter på kvetiapin i årene 2005-15, ble halvert i samme periode. I 2015 fikk 9,5\% av pasientene forskrevet $400 \mathrm{mg}$ eller mer daglig: 2,6\% på punkt $\mathrm{F}_{2}$ (psykoser), 1,5\% på punkt $\mathrm{F}_{3}$ (affektive lidelser) og 5,4 \% på hvit resept (1). Over $60 \%$ av pasientene som fikk forskrevet mer enn $400 \mathrm{mg}$ daglig, betalte altså for kvetiapin selv, og denne pasientgruppen er økende. Kvetiapin ble kun unntaksvis forskrevet på indikasjoner i samsvar med markedsføringstillatelsen.

Kvetiapin forskrives altså i all hovedsak til pasienter som verken er psykotiske eller har en psykoselidelse. Kunnskapsgrunnlaget for å bruke medikamentet på andre indikasjoner er svakt. Det finnes litt dokumentasjon når det gjelder generalisert angstlidelse og depresjon (3).Vårt inntrykk fra klinisk praksis er at kvetiapin ofte forskrives som et substitutt for benzodiazepiner, særlig for søvnvansker. Bruk av kvetiapin som sedativ/hypnotika er imidlertid svært dårlig dokumentert (4).

\section{Bivirkninger}

Kvetiapin har et betydelig bivirkningspotensial: ekstrapyramidale bivirkninger, trøtthet, vektøkning og andre metabolske forstyrrelser, antikolinerge og ortostatiske effekter og alvorlige kardiovaskulære hendelser. Metabolske bivirkninger ses allerede ved lave doser (5), og det finnes ingen nedre grense for doser som ikke medfører bivirkningsrisiko. Bruk utenfor godkjent indikasjon er i seg selv assosiert med økt risiko (6). I tillegg er risikoen for misbruk etter hvert godt dokumentert (7). Kvetiapin er det eneste antipsykotiske 
medikamentet som omsettes illegalt. Det faktum at over halvparten av pasientene som $\mathrm{i}$ 2015 brukte doser over $400 \mathrm{mg}$ ikke fikk medikamentet forskrevet på blå resept, kan reflektere misbruk. Kvetiapin synes å være mer toksisk ved overdose enn andre antipsykotika (8) og assosieres i terapeutiske sammenhenger med høyere dødelighet enn noe annet legemiddel i antipsykotikagruppen (9).

Kvetiapin bør forskrives på dokumenterte indikasjoner. Nåværende forskrivningsmønster i Norge reflekterer neppe god medisinsk praksis.

\section{LITTERATUR:}

1. Gjerden P, Bramness JG, Tvete IF et al. The antipsychotic agent quetiapine is increasingly not used as such: dispensed prescriptions in Norway 2004-2015. Eur J Clin Pharmacol 2017; 73: 1173 - 9.

[PubMed][CrossRef]

2. Nasjonale faglige retningslinjer, IS-1925. Bipolare lidingar. Nasjonal fagleg retningslinje for utgreiing og behandling av bipolare lidingar. Oslo: Helsedirektoratet, 2012.

https://helsedirektoratet.no/Lists/Publikasjoner/Attachments/105/IS-1925-Nasjonal-faglig-retningslinje -for-utgreiing-og-behandling-av-bipolare-lidingar.pdf (27-6.2018).

3. Maglione M, Maher AR, Hu J et al. Off-Label Use of Atypical Antipsychotics: An Update. AHRQ Comparative Effectiveness Reviews nr. 43. Rockville (Maryland): Agency for Healthcare Research and Quality(US), 2011.

4. Thompson W, Quay TAW, Rojas-Fernandez C et al. Atypical antipsychotics for insomnia: a systematic review. Sleep Med 2016; 22:13-7. [PubMed][CrossRef]

5. Cates ME, Jackson CW, Feldman JM et al. Metabolic consequences of using low-dose quetiapine for insomnia in psychiatric patients. Community Ment Health J 2009; 45: 251 - 4. [PubMed][CrossRef]

6. Eguale T, Buckeridge DL, Verma A et al. Association of off-label use and adverse drug events in adult population. JAMA Intern Med 2016; 176: 55 - 63. [PubMed][CrossRef]

7. Chiappini S, Schifano F. Is there a potential of misuse of quetiapine? Literature review and analysis of the European Medicines Agency/European Medicines Agency adverse drug reactions' database. J Clin Psychopharmacol 2018;38: 72 - 9. [PubMed]

8. Ngo A, Ciranni M, Olson KR. Acute quetiapine overdose in adults: a 5-year retrospective case series. Ann Emerg Med 2008; 52: 541 - 7. [PubMed][CrossRef]

9. Tiihonen J, Lönnqvist J, Wahlbeck Ket al. 11-year follow-up of mortality in patients with schizophrenia: a population-based cohort study (FIN11 study). Lancet 2009; 374: 620 - 7 . [PubMed][CrossRef]

Publisert: 3. september 2018. Tidsskr Nor Legeforen. DOI: 10.4045/tidsskr.18.0535

Mottatt 21.6.2018, godkjent 27.6.2018.

(C) Tidsskrift for Den norske legeforening 2020. Lastet ned fra tidsskriftet.no 